Revue belge de géographie

4 | 2016

Sustainability of rural systems: balancing heritage and innovation

\title{
Editorial: Sustainability of rural systems: balancing heritage and innovation
}

Serge Schmitz and Charline Dubois

\section{(2) OpenEdition}

Journals

Electronic version

URL: http://journals.openedition.org/belgeo/20123

DOI: $10.4000 /$ belgeo.20123

ISSN: 2294-9135

Publisher:

National Committee of Geography of Belgium, Société Royale Belge de Géographie

Electronic reference

Serge Schmitz and Charline Dubois, «Editorial: Sustainability of rural systems: balancing heritage and innovation », Belgeo [Online], 4 | 2016, Online since 22 September 2017, connection on 23 September 2020. URL : http://journals.openedition.org/belgeo/20123; DOI : https://doi.org/10.4000/belgeo. 20123

This text was automatically generated on 23 September 2020 .

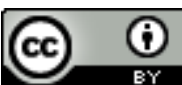

Belgeo est mis à disposition selon les termes de la licence Creative Commons Attribution 4.0 International. 


\title{
Editorial: Sustainability of rural systems: balancing heritage and innovation
}

\author{
Serge Schmitz and Charline Dubois
}

1 The Commission on the Sustainability of Rural Systems (CSRS) is one of the forty commissions of International Geographical Union. For twenty-five years, the Commission has worked towards achieving "a better understanding of rural areas and their sustainability in various regions of the world, taking care to address the multiple dimensions of sustainable environments, including agriculture, communities, housing, industrial and service employment, recreation and tourism, as well as extractive activities, forestry, and renewable energy production".

2 Our world is becoming increasingly urban. The countryside, given its distinctiveness and services provided, deserves attention as it faces important challenges. The spaces in the countryside are not at all empty to accommodate urban externalities and at the same time feed people using industrial agriculture processes. In most cases, rural spaces are inhabited and are inherited from a long history of domestication, but their richness and development potential are often underestimated within a fast growing liberal economy. Depending on the location, especially the distance from city centers and agricultural production potential, these areas could be deserted, focused on largescale agriculture, reinvested with post-productivist activities, became an outer-suburb, or developed into a vivid high-density countryside. This diversity of situations must be carefully analyzed to understand transformation processes, and highlight smart practices. Other than scientific and technological reading of the countryside, attention should be given to local knowledge prior to the suggestion of future recommendations.

On July 17 to 22,2016 , the $24^{\text {th }}$ annual Colloquium of the CSRS took place in Belgium, which was a particularly appropriate place to reflect on the sustainability of rural systems through the discussion about the new technologies and new rural ways of life, agronomic innovations, ecosystem and agro-services, energy issues, multiple functions of forests and countryside (with three focus on economy, environment and boundary 
concept), tourism or recreation development, and to analyze ways to balance cultural and natural heritage and innovation with focus on ecological and social dimensions (Schmitz et al., 2016). Around 60 researchers from 17 countries attended the colloquium. This special issue features selected papers from the colloquium and from papers submitted to Belgeo.

4 The CSRS, aimed at advancing academic discussions on the sustainability of rural systems, provides not just a venue for the sharing of original scientific works through the annual conference, but also local field experience in the host country through the organization of field activities and meetings with local stakeholders such as community members, managers, and professionals from various fields. In CSRS 2016, the first three days of the program provided rich discussions on rural systems development and practices around the world through the organized thematic sessions on rural experiences and innovation. The next three days, in collaboration with academics from Liège, Namur and Ghent universities, featured the local and regional rural development practices of Flanders and Wallonia.

5 Belgium is a densely populated country with a long history of land exploitation. The landscape is modified by humans through diverse agricultural practices, early urbanization and industrialization, the exploitation of quarries and mines and the dense development of canals, railways and motorway networks. Nevertheless, rural areas are important because farming activities, which are increasingly mechanized and technologically based, contribute to economic activities and boost Belgian exports. Moreover, agriculture plays an important role in maintaining open spaces and in offering services to new residents of the countryside and visitors.

30 years after the Brundlandt report, our moral obligation to guarantee the quality of life of future generations, avoid the increasing use of resources beyond the carrying capacity, and re-examine consumption and production patterns still exists (Robinson, 2008). Our world is our common heritage and that world includes rural areas. How do we maintain biodiversity and landscape quality to afford the need of the present and the future generations and enhance the rural capital? How do we tackle poverty, hunger, reduce inequalities and preserve natural life? While it is difficult to calculate the full profit and loss account of natural and cultural resources, it is evident that rural areas play a major role in achieving the 17 sustainable development goals of the United Nations.

7 In many regions of the world, both forests and agricultural lands are multifunctional. Different activities are based on the ecosystem services that form rural capitals. For instance, other than the economic function of the forest, recreation and environmental functions are increasingly integrated in forest management programs. There is now an increasing appreciation of symbolic value of the countryside. For example, heritage elements like hedges or ponds in France are being re-introduced to target several functions: to maintain biodiversity, support recreation activities, produce food and energy, increase visual attraction, and contribute to heritage conservation. The compatibility of several activities in one biotope, however, still raise issues (Douet, 2017; Mathis, 2017). The valorization of heritage elements depends largely on social capital and past development decisions (path dependency). In England, as another example, Robinson \& Robinson (2017) analyzed how the National Lottery contributed to the improvement of landscape heritage that paid little attention to the local people's point of view. In some cases, countryside becomes mere decor to residential areas or 
serves recreational purposes. Tourism indeed presents opportunities although its positive impacts may not be so evident.

8 Migration to rural areas affects rural economy, environment, culture and tradition, and place identity. The new connection with remote rural areas influences choices and practices. Nevertheless, such processes have the tendency to improve living conditions, they can also reinforce the remoteness of people and places on the wrong side of the digital divide. With the development and proliferation of new information and communication technologies, the remoteness of some areas of the countryside has become less important. New economic activities are possible including, for instance, those relating to light industry or to call services. New technologies, along with distance contraction and redistribution of people and activities, resulted to new consumption patterns that reshaped rural cultures and ways of life. However, new opportunities are not without risks and challenges. Kumer \& Potocnik (2017) examine the forest management orientations between "urban" and "rural" small-scale forest owners in Slovenia. They analyze how conflicts of interest impede cooperation and rational forest management. Meanwhile, agricultural practices, including organic agriculture, are increasingly linked with agronomic research and innovations. Rudnicki et al. (2017) analyze agricultural statistical data and point out that while the EU policy contributed largely to the diversification of income structure of farming in Poland, the aging rural population raises new social challenges.

Three papers in this issue put forward social and environmental approaches that effectively address sustainability of countryside systems. Innovation impacts landscapes and could promote the preservation of landscapes as heritage sites. It may also affect rural society by determining the extent in which farmers and traditional knowledge are included in the development process. Bicalho \& Peixoto (2017) discuss the importance of the bridging of local and scientific knowledge in building agroecological systems in the Brazilian Atlantic Forest. Meanwhile, Ciervo (2017) questions the government's response to address the spread of the xylella fastidiosa $(x f)$ bacteria in the olive oil producing region in southern Italy, which could lead to irreversible social and environmental impacts. In the Paraguay River, Hoefle \& Bicalho (2017) contrast the biocentric conservation policy with the historic ways of fisher-farmers. They discuss two ways of domesticating nature, which impact is worse within a pseudo conservationist approach.

10 This special issue highlights the importance of societal factors in rural system development. Technological innovation is effective if it takes into consideration community diversity and recognizes its tendency to reshape environmental and social systems. Bousbaine \& Bryant (2017) provide a good example by studying the alternative food systems in south Belgium. The renaissance of local food market reconnected the city to its agricultural hinterland, resulted to the renewed interest in agriculture, and revitalized the economy. Nguyen et al. (2017), on the other hand, show the resilience of an ethnic minority in Vietnam border to adjust centralized state territorialisation by using traditional cross-border cultural resources.

11 The common theme that connects all conference communications is the agreement that amidst rural system transformations, progress or renewal via farming activities, recreation, physical and digital mobility or environmental change, it is important to balance heritage conservation and rural innovation. Paradoxes have been identified concerning tourist development and sustainability, the lack of acknowledgment of 
ecosystem services, local and regional resilience in the context of contemporary global rural discourse regarding the physical or economic environment, or the evolution of the structures of the territory.

The theme of the colloquium centered on the balance between rural heritage and innovation. The papers in this issue emphasize that territorial engineering and management of the transition is part of the current reflections on the sustainability of rural development. There is consensus that the rural world must also allow for the positive redefinition of its spaces. New potentials and complementarities are possible between rural tourism, agricultural activities, other economic activities, cultural attractions, environmental sustainability, local identity, and landscapes. These are achieved through the reinterpretation of spaces, exploration of new economic horizons, creation of new relationships through rural integration (via lifestyle, mobility and environmental work), innovation and technological revolution, and the accommodation of new models and forces that drive social and environmental change. A sustainable rural system is one that innovates not only technically but also balances the social, economic and cultural aspects of rural capital. However, some questions remain. Given the positive aspects of rural development, including positive attitudes, can they be replicated in other regions? Are they needed elsewhere? Is there sustainability in the maintenance of local knowledges, resources, identities, and ways of life?

\section{BIBLIOGRAPHY}

ROBINSON G.M. (ed.) (2008), Sustainable rural systems: Sustainable agriculture and rural communities, Ashgate Publishing Ltd.

SCHMITZ S., DUBOIS C., CAWLEY M. \& M. CIERVO (eds.) (2016), Sustainability of Rural Systems: Balancing Heritage and Innovation, $24^{\text {th }}$ Colloquium of the Commission on the Sustainability of Rural Systems of the International Geographical Union, Liège, Atelier des Presses. 